\title{
PENGARUH LIKUIDITAS DAN LEVERAGE TERHADAP PROFITABILITAS PADA PT HANJAYA MANDALA SAMPOERNA, TBK YANG TERDAFTAR DI BURSA EFEK INDONESIA
}

\author{
Oleh: \\ Murni Sari Dewi Saragih \\ S1 Akuntansi \\ Liper Siregar, Efendi, Ady Inrawan
}

Abstraksi

Tujuan dari penelitian ini adalah untuk mengetahui Likuiditas, Leverage dan Profitabilitas serta pengaruh Likuiditas dan Leverage terhadap Profitabilitas pada PT Hanjaya Mandala Sampoerna, Tbk Yang Terdaftar Di Bursa Efek Indonesia baik secara simultan maupun parsial. Metode analisis yang digunakan dalam penelitian ini adalah metode analisis deskriptif kualitatif dan analisis deskriptif kuantitatif. Objek penelitian ini adalah PT Hanjaya Mandala Sampoerna, Tbk yang terdaftar di Bursa Efek Indonesia tahun 2009 sampai tahun 2015. Metode yang digunakan untuk analisis data dalam penelitian ini adalah uji asumsi klasik, analisis regresi linier berganda, koefisien korelasi, koefisien determinasi, dan uji hipotesis (uji F dan uji t). Pengujian dilakukan dengan menggunakan bantuan program IBM SPSS Statistics versi 20,0.

Hasil analisa dari regresi linier berganda yaitu: $\hat{Y}=0,116+0,018 \mathrm{X}_{1}+0,546 \mathrm{X}_{2}$. Hal ini menunjukkan bahwa terdapat pengaruh positif antara likuiditas dan leverage terhadap profitabilitas. Hasil kolerasi yaitu $\mathrm{r}=0,760$ yang berarti terdapat hubungan yang kuat antara variabel bebas dengan variabel terikat. Koefisien determinasi adalah sebesar 0,578 yang berarti bahwa 57,8\% dari profitabilitas dijelaskan oleh Likuiditas dan Leverage. Sedangkan sisanya $42,2 \%$ dijelaskan oleh faktor lainnya. Hipotesis penelitian $\mathrm{H}_{0}$ diterima, artinya likuiditas dan leverage berpengaruh tidak signifikan terhadap profitabilitas pada PT Hanjaya Mandala Sampoerna, Tbk yang terdaftar di Bursa Efek Indonesia baik secara simultan maupun parsial.

Kata Kunci: Likuiditas, Leverage dan Profitabilitas

\section{Abstraction}

The purpose of this research are to identify the description of liquidity, leverage and profitability and analyze the effect of Liquidity and Leverage on Profitability at PT Hanjaya Mandala,Tbk listed in Indonesia Stock Exchange either simultanly or partially. Methods of analysis used in this study are descriptive analysis of qualitative methods and quantitative descriptive analysis. The object of this research is PT Astra Otoparts, Tbk listed in the Indonesia Stock Exchange from 2006 until 2015 with the criteria as much as 10 years. The method used for data analysis in this study is the classical assumption test, multiple linear regression analysis, the correlation coefficient of determination, and hypothesis test ( $F$ test and t test). Data analysis was performed by using IBM SPSS Statistic version 20,0.

Result of analysis multiple linear regression that is $\hat{Y}=0,116+0,018 X_{1}+0,546 X_{2}$. This shows that there is positive correlation between liquidity and leverage with profitability. The test results of correlation is $r=0,760$, which means there is strong correlation between independent variables with dependent variabel. The coefficient of determination is 0,57,8, wich means $57,8 \%$ of profitability is explained by liquidity and leverage ratio. While the remaining 42,2\% is explained by other factors.. Research hypothesis $H_{0}$ is accepted, which means liquidity and leverage are not significant effect to profitability at PT Hanjaya Mandala,Tbk listed in Indonesia either partially or simultanly.

Keywords: liquidity, Leverage and Profitability

\section{A. PENDAhuluan}

1. Latar Belakang Masalah

Laporan keuangan adalah suatu proses akuntansi yang menyajikan informasi yang berupa data keuangan yang membantu dalam melaksanakan pengambilan keputusan-keputusan bagi pihak yang berkepentingan. Para investor yang ingin menanamkan modal di suatu perusahaan akan melihat laporan keuangan untuk melihat sejauh mana perkembangan perusahaan. Para investor biasanya memfokuskan pada analisis profitabilitas sebelum melakukan investasi pada suatu perusahaan. Oleh karena itu, perusahaan dituntut harus selalu menjaga kondisi profitabilitasnya agar dapat stabil sehingga investor akan tertarik untuk berinvestasi pada perusahaan tersebut.

Dengan profitabilitas yang stabil perusahaan akan dapat menjaga kelangsungan usahanya, sebaliknya apabila perusahaan tidak mampu untuk menghasilkan profitabilitas yang memuaskan maka perusahaan tidak akan mampu menjaga kelangsungan usahanya. Faktor-faktor yang mempengaruhi profitabilitas adalah rasio likuiditas, rasio solvabilitas (leverage), rasio manajemen aset, penjualan, efisiensi modal kerja, profit margin, dan struktur modal. Salah satu indikator profitabilitas yang diukur untuk mengukur kinerja keuangan perusahaan adalah Return on Equity (ROE). ROE

\begin{tabular}{lllll}
\hline \hline Jurnal SULTANIST & ISSN : 2338-4328 & Vol. 5, No. 2, & DESEMBER 2016 & 59
\end{tabular}


menunjukkan kemampuan perusahaan untuk menghasilkan laba setelah pajak dengan menggunakan modal sendiri yang dimiliki perusahaan. Semakin tinggi rasio ini berarti semakin efisien penggunaan modal sendiri yang dilakukan oleh pihak manajemen perusahaan.

Rasio likuditas merupakan rasio keuangan yang menggambarkan kemampuan perusahaan untuk membayar utang, utang jangka pendek. Indikator yang digunakan adalah rasio Lancar atau Current Ratio (CR) merupakan perbandingan antara aset lancar dengan kewajiban jangka pendek dan merupakan ukuran perbandingan antara aset lancar dengan kewajiban jangka pendek.

Leverage adalah suatu rasio yang digunakan untuk mengukur kemampuan perusahaan dalam melunasi semua utang yang digunakan dalam membiayai perusahaan. Debt to Equity Ratio (DER) Merupakan rasio yang sering digunakan untuk menilai utang dengan ekuitas. Untuk mencari rasio ini dengan membandingkan antara seluruh utang, termasuk utang lancar dengan seluruh ekuitas. Rasio ini berguna untuk mengetahui jumlah dana yang disediakan peminjam (kreditor) dengan pemilik perusahaan. Dengan kata lain, rasio ini berfungsi untuk mengetahui setiap rupiah modal sendiri yang dijadikan untuk jaminan utang.

\section{Rumusan Masalah}

a. Bagaimana gambaran Likuiditas, Leverage dan Profitabilitas pada PT Hanjaya Mandala Sampoerna, Tbk yang Terdaftar Di Bursa Efek Indonesia?

b. Bagaimana pengaruh Likuiditas dan Leverage terhadap Profitabilitas pada PT Hanjaya Mandala Sampoerna, Tbk yang Terdaftar Di Bursa Efek Indonesia baik secara simultan maupun parsial?

\section{Tujuan Penelitian}

a. Untuk mengetahui gambaran Likuiditas, Leverage dan Profitabilitas pada PT Hanjaya Mandala Sampoerna, Tbk yang Terdaftar Di Bursa Efek Indonesia.

b. Untuk mengetahui pengaruh Likuiditas dan Leverage terhadap Profitabilitas pada PT Hanjaya Mandala Sampoerna, Tbk yang Terdaftar Di Bursa Efek Indonesia baik secara simultan maupun parsial.

\section{Metode Penelitian}

Dalam penelitian ini, penulis mengambil objek penelitian pada PT Hanjaya Mandala Sampoerna, Tbk yang terdaftar di Bursa Efek Indonesia yang beralamat di Jl. Rungkut Industri Raya No. 18 Surabaya 60293 Indonesia dengan cara mengakses data yang bersumber dari situs www.idx.co.id dan www. Sampoerna.com

Adapun desain penelitian yang digunakan dalam penulisan skripsi ini adalah penelitian kepustakaan (library research). Teknik pengumpulan data yang dilakukan penulis dalam penelitian ini adalah dokumentasi. Adapun jenis data yang digunakan dalam penelitian ini adalah jenis data kualitatif dan data kuantitatif. Hasil data yang diperoleh akan dianalisis secara deskriptif baik bersifat kualitatif dan kuantitatif.

\section{B. LANDASAN TEORI}

\section{Laporan Keuangan}

Dalam Standar Akuntan Keuangan (SAK) per 1 Oktober 2004 yang dirumuskan oleh Ikatan Akuntan Indonesia (2004:2), laporan keuangan merupakan bagian dari proses pelaporan keuangan. Laporan keuangan yang lengkap biasanya meliputi neraca, laporan laba rugi, laporan perubahan posisi keuangan, catatan dan laporan lain serta materi penjelasan merupakan bagian integral dari laporan keuangan.

Menurut PSAK dalam Martani, dkk (2012:9), laporan yang dihasilkan oleh suatu entitas sebagai berikut:

a. Laporan posisi keuangan adalah daftar yang sistematis dari aset, utang, dan modal pada tanggal tertentu, yang biasanya dibuat pada akhir tahun.

b. Laporan laba rugi komprehensif adalah ikhtisar mengenai pendapatan dan beban suatu entitas untuk periode tertentu, sehingga dapat diketahui laba yang diperoleh dan rugi yang dialami.

c. Laporan arus kas, dengan adanya laporan ini, pemakai laporan keuangan dan mengevaluasi perubahan aset neto entitas, struktur keuangan (termasuk likuiditas dan solvabilitas) dan kemampuan entitas untuk menghasilkan kas di masa mendatang.

d. Laporan perubahan ekuitas adalah laporan yang menunjukkan perubahan ekuitas untuk periode tertentu, bisa satu bulan atau satu tahun.

e. Catatan atas laporan keuangan merupakan laporan yang berisi informasi tambahan atas apa yang disajikan dalam empat laporan di atas. Laporan ini memberikan penjelasan atau rincian pos-pos yang disajikan dalam laporan keuangan dan informasi mengenai pos-pos yang tidak memenuhi kriteria pengakuan dalam laporan keuangan.

\section{Analisis Rasio Keuangan}

Menurut Horne dan John (2012:154), analisis laporan keuangan yaitu seni untuk mengubah data dari laporan keuangan menjadi informasi yang berguna bagi pengambilan keputusan. Menurut Kasmir (2010:90), analisis laporan keuangan perlu dilakukan agar laporan keuangan dapat dipahami dan dimengerti oleh berbagai pihak sehingga laporan keuangan menjadi lebih berarti. Hasil analisis laporan keuangan juga akan memberikan informasi tentang kelemahan dan kekuatan yang dimiliki oleh perusahaan. Adapun jenis-jenis teknik analisis laporan keuangan yang dapat dilakukan adalah sebagai berikut:

a. Analisis perbandingan antara laporan keuangan.

b. Analisis trend.

c. Analisis persentase per komponen.

d. Analisis sumber dan penggunaan data.

e. Analisis sumber dan penggunaan kas. 
f. Analisis rasio.

g. Analisis kredit.

h. Analisis laba kotor.

i. Analisis titik pulang pokok atau titik impas (break even point)

Dari berbagai teknik analisis laporan keuangan penulis menggunakan metode analisis rasio untuk penelitian ini. Rasio keuangan digunakan untuk mengevaluasi kondisi keuangan dan kinerja perusahaan. Menurut Brigham dan Joel (2010:154), rasio keuangan yang sering digunakan adalah sebagai berikut:

a. Rasio likuditas (likuidity ratio)

Rasio likuditas (likuidity ratio), yaitu rasio yang menunjukkan hubungan antara kas dan aset lancar perusahaan dengan kewajiban lancarnya. Rasio yang umum digunakan yaitu: Rasio lancar (current ratio) dan Rasio cepat (quick ratio atau acid ratio).

b. Rasio manajemen aset (assets manajemen ratio) Rasio manajemen aset (assets manajemen ratio), yaitu rasio yang mengukur seberapa efektif sebuah perusahaan mengatur asetnya. Rasio manajemen aset yang sering digunakan yaitu: Rasio perputaran persediaan (inventory turn over ratio), Jumlah hari penjualan belum tertagih (days sales outstanding-DSO), Rasio perputaran aset tetap (fixed assets turn over ratio) dan Rasio perputaran total aset (total assets turn over ratio)

c. Rasio manajemen utang (financial leverage ratio), Rasio manajemen utang (financial leverage ratio) yaitu rasio yang mengukur sampai sejauh apa perusahaan menggunakan pendanaan melalui utang. Rasio yang digunakan adalah: Total utang terhadap total aset/rasio utang (debt ratio), Rasio kelipatan pembayaran bunga (time interest earned-TIE) dan Rasio cakupan EBITDA (EBITDA coverage ratio).

d. Rasio profitabilitas (Profitability ratio)

Rasio profitabilitas (Profitability ratio) yaitu sekelompok rasio yang menunjukkan kombinasi dan pengaruh likuiditas, manajemen aset, dan utang pada hasil operasi. Rasio umum digunakan yaitu: Margin laba atas penjualan (profit margin on sales), Pengembalian atas total aset (return on total assets- ROA), Rasio kemampuan dasar untuk menghasilkan laba (basic earning powerBEP) dan Rasio pengembalian atas ekuitas biasa (return on common equity-ROE).

\section{Likuiditas}

Menurut Atmaja (2008:415), rasio likuiditas adalah mengukur kemampuan perusahaan untuk memenuhi kewajiban-kewajiban yang jatuh tempo.

Berikut adalah jenis-jenis rasio likuiditas yang lazim digunakan dalam praktik untuk mengukur kemampuan perusahaan dalam memenuhi kewajiban jangka pendek (Kasmir 2010:110).

a. Rasio Lancar

Rasio ini menunjukkan kemampuan perusahaan untuk membayar liabilitas jangka pendek dengan menggunakan aset lancarnya.

\section{Rasio Lancar $=\frac{\text { Aset Lancar }}{\text { Liabilitas Jangka Pendek }}$}

Semakin tinggi rasio lancar, maka akan semakin besar kemampuan perusahaan untuk membayar berbagai tagihannya.

b. Rasio Cepat

Rasio ini menunjukkan kemampuan perusahaan untuk memenuhi liabilitas jangka pendek dengan aset yang paling likuid (cepat).

Rasio Cepat $=\frac{\text { Aset Lancar-Persediaan }}{\text { Liabilitas Jangka Pendek }}$

Rasio ini berkonsentrasi terutama hanya pada aset lancar yang lebih likuid, yaitu kas, sekuritas yang dapat diperjualbelikan, piutang, dan hubungannya dengan berbagai obligasi jangka pendek.

Dalam penelitian ini, rasio likuiditas diukur dengan menggunakan rasio lancar (current ratio) karena angka rasio lancar yang rendah memperlihatkan likuiditas perusahaan yang kurang baik. Sebaliknya, angka rasio lancar yang tinggi menunjukkan adanya pengelolaan harta yang kurang atau tidak efisien, misalnya jumlah persediaan yang berlebihan.

\section{Leverage}

Menurut Kasmir (2010:112), rasio solvabilitas atau leverage merupakan rasio yang digunakan untuk mengukur sejauh mana aktiva perusahaan dibiayai dengan hutang. Artinya, seberapa besar utang yang ditanggung perusahaan dibandingkan dengan aktivanya.

Rasio manajemen hutang/leverage dibagi menjadi tiga menurut Brigham dan Joel (2010:143), antara lain:

a. Total utang terhadap total aset, yang umumnya disebut rasio utang (debt ratio), yaitu mengukur persentase dana yang diberikan oleh kreditor.

Rasio Hutang $=\frac{\text { Total Hutang }}{\text { Total Aktiva }}$

b. Rasio kelipatan pembayaran bunga (tim-interstearned-TIE) dihitung dengan membagi laba sebelum pajak (EBIT) dengan beban bunga. Rasio TIE mengukur sampai sejauh apa laba operasi dapat mengalami penurunan.

Rasio Kelipatan Pembayaran Bunga = Laba Bersi Sebelum tounga dan Pajak

c. Rasio cakupan EBITDA berguna untuk menilai kemampuan perusahaan dalam memenuhi beban buriga atas utang.

Rasio Cakupan EBITDA

EBITDA+Pembayaran Sewa Guna Usa a

Bunga+Pembayaran Pokok+Pembayaran Sewa

Dalam penelitian ini, rasio leverage diukur dengan menggunakan debt to equity ratio (DER). DER merupakan rasio utang yang digunakan untuk mengukur seberapa besar modal perusahaan dibiayai oleh utang atau seberapa besar utang perusahaan berpengaruh terhadap pengelolaan modal sendiri perusahaan. Semakin tinggi rasio ini berarti semakin besar jumlah modal pinjaman yang digunakan untuk investasi pada aktiva guna menghasilkan keuangan bagi perusahaan. 


\section{Profitabilitas}

Menurut Brigham dan Joel (2010:146), rasio profitabilitas mencerminkan hasil akhir seluruh kebijakan keuangan dan keputusan operasional. Menurut Sudana (2011:32), rasio-rasio yang termasuk dalam rasio profitabilitas adalah:

a. Return On Asset (ROA), menggambarkan perusahaan dengan mengggunakan seluruh aset yang dimiliki untuk menghasilkan laba setelah pajak. Semakin bebesar ROA berarti semakin efisiensi penggunaan aset perusahaan. Untuk mengukur rasio ini digunakan rumus:

Return On Asset $(\mathrm{ROA})=$ Laba Bersih Setelah Pajak

b. Return On Equity (ROE), menunjukkan kemampuan perusahaan untuk menghasilkan laba setelah pajak dengan menggunakan modal sendiri yang dimiliki perusahaan. Untuk mengukur rasio ini digunakan rumus:

$$
\text { Return On Equity }(\mathrm{ROE})=\frac{\text { Laba Setelah Pajak }}{\text { Modal Sendiri }}
$$

c. Net Margin atau Profit Margin on Sales, mengukur kemampuan di perusahaan untuk menghasilkan laba dengan menggunakan penjualan yang dicapai perusahaan. Semakin tinggi rasio ini menunjukkan bahwa perusahaan semakin efisiensi dalam menjalankan operasinya untuk mengukur net margin dengan rumus:

Profit Margin $=$ Penjualan Bersih - Harga Pokok Penjualan

d. Basic Earning Power (BEP), mengukur kemampuan perusahaan untuk menghasilkan laba sebelum bunga dan pajak dengan menggunakan total aset yang dimiliki perusahaan. Rumus yang digunakan adalah:

Basic Earning Power $(\mathrm{BEP})=\frac{\text { Laba Sebelum Pajak }}{}$

Dalam penelitian ini, rasio profitahilitas diukur dengan menggunakan return on equity (ROE). Rasio ini penting bagi pemegang saham untuk mengetahui efektivitas dan efisiensi pengelolaan modal sendiri yang dilakukan oleh pihak manajemen perusahaan. Semakin tinggi rasio ini berarti semakin efisien penggunaan modal sendiri yang dilakukan oleh pihak manajemen perusahaan.

\section{Pengaruh Likuiditas dan Leverage} Terhadap Profitabilitas

Menurut Horne dan John (2012:167), likuiditas perusahaan berbanding terbalik dengan profitabilitas. Maksudnya, semakin tinggi likuiditas perusahaan maka kemampuan perusahaan untuk menghasilkan laba semakin rendah. Menurut Mardiyanto (2008:99), likuiditas yang tinggi merupakan indikator bahwa risiko perusahaan rendah. Artinya, perusahaan aman dari kemungkinan kegagalan membayar berbagai kewajiban lancar. Namun, hal ini harus dicapai dengan merelakan rendahnya tingkat profitabilitas, yang akan berdampak terhadap pertumbuhan perusahaan.

Berdasarkan signalling theory, perusahaan yang mampu menghasilkan laba cenderung meningkatkan jumlah utangnya. Karena tambahan pembayaran bunga akan diimbangi dengan laba sebelum pajak (Sudana, 2011:153). Sedangkan menurut Pecking Order Theory. Besarnya rasio leverage membuat perusahaan harus mengemban tingginya biaya bunga yang harus dipenuhi, sehingga hal ini akan berdampak pada penurunan profitabilitas perusahaan.

\section{PEMBAHASAN}

\section{Analisa}

\section{a. Uji Asumsi Klasik}

Uji normalitas dengan pengujian One Sample Kolmogorov-Smirnov diperoleh nilai Asymp Sig. (2tailed) sebesar 1,008 yang berarti nilai tersebut di atas nilai signifikan atau 1,008>0,05. Dengan demikian dapat dikatakan bahwa variabel residual berdistribusi normal. Untuk uji multikolineritas, monunjukkan bahwa nilai TOL (Tolerance) variabel CR dan DAR sebesar 0,121, sedangkan nilai VIF (Veriance Infloating Factor) variabel CR dan DAR sebesar 8,248 lebih kecil dari 10, maka pada model regresi yang terbentuk tidak terjadi gejala multikolinieritas.

Dari grafik scatterplot terlihat bahwa plot menyebar secara acak di atas maupun di bawah angka nol pada sumbu Regression Studentized Residual. Oleh karena itu, maka berdasarkan uji heteroskedastisitas menggunakan metode analisis grafik, pada model regresi yang terbentuk dinyatakan tidak terjadi gejala heteroskedastisitas. Nilai DurbinWatson dalam penelitian ini adalah sebesar 1,065. Berdasarkan tabel Durbin-Watson dengan n-k-1 (82-1=5), yaitu 5 vs 2 maka akan diperoleh nilai $\mathrm{dL}=0,559, \mathrm{dU}=1,777,4-\mathrm{dL}=3,441$ dan $4-\mathrm{dU}=2,223$. Karena nilai Durbin-Watson $(1,065)$ terletak antara dL dan dU maka dapat disimpulkan bahwa model persamaan regresi tersebut tanpa kesimpulan.

\section{Deskriptif Kualitatif}

Analisis deskriptif dalam penelitian ini bertujuan untuk mendapatkan gambaran atau deskripsi mengenai likuiditas, leverage dan profitabilitas pada PT Hanjaya Mandala Sampoerna, Tbk yang terdaftar di Bursa Efek Indonesia periode 2008-2015.

1) Likuiditas pada PT Hanjaya Mandala Sampoerna, Tbk yang terdaftar di Bursa Efek Indonesia Tahun 2008-2015

Dari hasil penelitian, terlihat bahwa nilai likuiditas yang diukur dengan Current Ratio (CR) cenderung mengalami kenaikan setiap tahunnya. CR minimum perusahaan tahun 2008-2015 adalah sebesar 1,444 pada tahun 2008. CR maksimum perusahaan tahun 2008-2015 adalah sebesar 6,567 pada tahun 2015. Hal ini disebabkan oleh peningkatan aset lancar yang tinggi dibandingkan dengan liabilitas jangka pendek.Nilai rata-rata dari likuiditas yang diukur dengan Current Ratio (CR) adalah sebesar 2,289.

2) Leverage pada PT Hanjaya Mandala Sampoerna, Tbk yang terdaftar di Bursa Efek Indonesia Tahun 2008-2015 
Dari hasil penelitian, terlihat bahwa nilai Leverage yang diukur dengan Debt to Equity Ratio (DER) cenderung mengalami penurunan setiap tahunnya. DER minimum perusahaan tahun 2008 2015 adalah sebesar 1,158 pada tahun 2015. Hal ini disebabkan oleh peningkatan total ekuitas yang tinggi, terjadi peningkatan modal saham dan tambahan modal disetor dari tahun sebelumnya. DER maksimum perusahaan sebesar 1,103 pada tahun 2014 Hal ini disebabkan oleh peningkatan total liabilitas meningkat lebih tinggi dibandingkan dengan total aset perusahaan.

3) Profitabilitas pada PT Hanjaya Mandala Sampoerna, Tbk yang terdaftar di Bursa Efek Indonesia tahun 2008-2015

Dari hasil penelitian, diketahui nilai Profitabilitas yang diukur dengan Return on equity (ROE) cenderung mengalami kenaikan setiap tahunnya. ROE minimum perusahaan tahun 20082015 adalah sebesar 0,324 pada tahun 2015. Hal ini disebabkan oleh peningkatan total ekuitas tidak sebanding dengan peningkatan laba di tahun 2015 ROE maksimum perusahaan tahun 2008-2015 adalah sebesar 0,790 pada tahun 2011. Hal ini disebabkan oleh peningkatan laba bersih tidak sebanding dengan peningkatan total ekuitas perusahaan. Nilai rata-rata ROE perusahaan tahun 2008-2015 adalah sebesar 0,622 .

\section{b. Deskriptif Kuantitatif}

\section{1) Analisis Regresi Linier Berganda}

Berdasarkan hasil analisa dengan program

SPSS, maka model regresi linear berganda yaitu

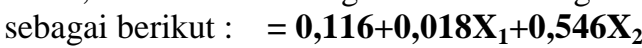

Artinya likuiditas dan leverage berpengaruh terhadap profitabilitas pada PT Hanjaya Mandala Sampoerna, Tbk tahun 2008-2015.

\section{2) Analisa Korelasi dan Determinasi}

Berdasarkan hasil pengolahan data SPSS diperoleh nilai koefisien korelasi adalah sebesar 0,760 yang berarti bahwa terdapat korelasi atau hubungan yang kuat antara variabel Current Ratio (CR) dan Debt to Equity Ratio (DER) dengan Return on Equity (ROE).

Untuk nilai koefisien determinasi adalah sebesar 0,578 hal ini menunjukkan persentase sumbangan pengaruh variabel likuiditas $\left(\mathrm{X}_{1}\right)$ dan leverage $\left(\mathrm{X}_{2}\right)$ terhadap variabel profitabilitas $(\mathrm{Y})$ $57,8 \%$ dijelaskan oleh dari kedua variabel independen, sedangkan sisanya $42,2 \%$ dipengaruhi atau di jelaskan variabel lain yang tidak dimasukkan dalam model penelitian ini.

\section{3) Uji Hipotesis}

\section{a) Uji Simultan (Uji F)}

Uji F menunjukkan apakah semua variabel independen yang dimasukkan dalam model regresi mempunyai pengaruh secara bersama-sama terhadap variabel dependen

Uji ini dilakukan dengan membandingkan signifikansi F dengan ketentuan sebagai berikut:
(1) $\mathrm{H}_{0}=0$, artinya likuiditas dan leverage berpengaruh tidak signifikan terhadap profitabilitas pada PT Hanjaya Mandala Sampoerna, Tbk yang terdaftar di Bursa Efek Indonesia.

(2) $\mathrm{H}_{\mathrm{a}} \neq 0$, artinya likuiditas dan leverage berpengaruh signifikan terhadap profitabilitas pada PT Hanjaya Mandala Sampoerna, Tbk yang terdaftar di Bursa Efek Indonesia.

Dari hasil pengolahan data, diperoleh nilai $\mathrm{F}_{\text {tabel }}$ dengan derajat bebas: df: $(0,05),(2$ vs 5$)$ adalah sebesar 5,79. Berdasarkan tabel di atas diperoleh $\mathrm{F}_{\text {hitung }}$ sebesar 3,420 dan nilai ini kecil dari $\mathrm{F}_{\text {tabel }}$ sebesar 5,79 atau dapat dikatakan 3,420<5,79 sementara nilai probabilitas $(0,116)$ lebih besar dari nilai $(0,05)$ atau dapat dikatakan $0,116>0,05$ maka $\mathrm{H}_{0}$ diterima. Hal ini berarti secara simultan likuiditas dan leverage berpengaruh tidak signifikan terhadap profitabilitas pada PT Hanjaya Mandala Sampoerna, Tbk yang terdaftar diBursa Efek Indonesia.

\section{b) Uji Parsial (Uji t)}

Uji t dilakukan untuk menguji signifikan tidaknya pengaruh antara variabel independen terhadap variabel dependen dengan asumsi bahwa variabel lain dianggap konstan.

Adapun uji hipotesis adalah sebagai berikut:

(1) $\mathrm{H}_{0}=0$, atau nilai signifikansi ditolak artinya likuiditas dan leverage berpengaruh tidak signifikan terhadap profitabilitas pada PT Hanjaya Mandala Sampoerna, Tbk yang terdaftar di Bursa Efek Indonesia secara parsial.

(2) $\mathrm{H}_{\mathrm{a}} \neq 0$, atau nilai signifikansi diterima artinya likuiditas dan leverage berpengaruh signifikan terhadap profitabilitas pada PT Hanjaya Mandala Sampoerna, Tbk yang terdaftar di Bursa Efek Indonesia secara parsial. berikut:

Dari hasil uji t diperoleh kesimpulan sebagai

(1) Current ratio (CR) mempunyai nilai $t_{\text {hitung }}$ sebesar 0,220 lebih kecil dari $t_{\text {tabel }}$ 2,571 atau dapat $0,220<2,571$. Sementara nilai probabilitas CR $(0,835)$ lebih besar dari $(0,05)$, atau dapat dikatakan $0,835>0,05$, maka $\mathrm{H}_{0}$ diterima atau dapat dikatakan CR berpengaruh tidak signifikan terhadap ROE pada PT Hanjaya Mandala Sampoerna, Tbk yang terdaftar di Bursa Efek Indonesia.

(2) Debt to Equity Ratio (DER) mempunyai nilai $\mathrm{t}_{\text {hitung }}$ sebesar 1,113 lebih kecil dari $\mathrm{t}_{\text {tabel }}$ 2,571 atau dapat dikatakan $1,113<2,571$ Sementara nilai probabilitas DAR $(0,316)$ Lebih besar dari

$(0,05)$, atau dapat dikatakan $0,316>0,05$, maka $\mathrm{H}_{0}$ diterima atau dapat dikatakan DER berpengaruh tidak signifikan terhadap ROE pada PT Hanjaya Mandala Sampoerna, Tbk yang terdaftar di Bursa Efek Indonesia.

\section{Evaluasi}

a. Likuiditas Pada PT Hanjaya Mandala Sampoerna, Tbk yang terdaftar di Bursa Efek Indonesia 
Dari hasil penelitian menunjukkan kondisi likuiditas perusahaan tahun 2008-2015 yang diukur dengan Current Ratio (CR) cenderung mengalami kenaikan setiap tahunnya. Secara keseluruhan nilai CR berada di bawah rata-rata kecuali pada tahun 2015. Diketahui CR minimum perusahaan tahun 2008-2015 adalah sebesar 1,444 pada tahun 2008 . Sebaiknya perusahaan dalam menentukan likuiditas sebuah perusahaan, perlu adanya pengendalian aktiva lancar.

CR maksimum perusahaan tahun 2008-2015 adalah sebesar 6,567 pada tahun 2015. Sebaiknya perusahaan lebih memperhatikan faktor-faktor untuk menjaga tingkat kestabilan CR. Dalam menentukan CR perlu adanya pengendalian aktiva lancar seperti perputaran kas, piutang dan persediaan sangat mempengaruhi tingkat likuiditas. Sampoerna, Tbk yang terdaft Indonesia

Dari hasil penelitian menunjukkan kondisi leverage Pada PT Hanjaya Mandala Sampoerna, Tbk tahun 2008-2015 yang diukur dengan menggunakan debt to equity ratio (DER) cenderung mengalami penurunan setiap tahunnya. Nilai rata-rata DER perusahaan tahun 2008-2015 adalah sebesar 0,851. Nilai DER yang berada di bawah rata-rata terjadi pada tahun 2009 dan 2015. Hal ini terlihat dari laporan keuangan yang disebabkan karena peningkatan modal perusahaan dan penurunan liabilitas. Diketahui DER minimum perusahaan tahun 2008-2015 adalah sebesar 0,187 pada tahun 2015. DER maksimum perusahaan sebesar 1,103 pada tahun 2014. Sebaiknya perusahaan menghindari rasio DER yang tinggi karena akan berpengaruh pada kelangsungan hidup perusahaan dimasa yang akan datang.

c. Profitabilitas Pada PT Hanjaya Mandala Sampoerna, Tbk yang terdaftar di Bursa Efek Indonesia

Dari hasil penelitian menunjukkan kondisi profitabilitas PT Hanjaya Mandala Sampoerna, Tbk tahun 2008-2015 yang diukur dengan ROE mengalami fluktuasi setiap tahunnya. Kondisi ini terlihat dari rata-rata ROE Nilai rata-rata ROE perusahaan tahun 2008-2015 adalah sebesar 0,622. Nilai ROE yang berada di bawah nilai Rata-rata terjadi pada tahun 2008, 2009 dan 2015. Hal ini disebabkan kenaikan laba bersih yang diikuti dengan kenaikan modal perusahaan.

ROE minimum perusahaan tahun 2008-2015 adalah sebesar 0,324 pada tahun 2015. Ini menunjukkan bahwa perusahaan hanya mampu menghasilkan laba laba bersih $32,4 \%$ dari total modal yang digunakan. ROE maksimum PT Hanjaya Mandala Sampoerna, Tbk sebesar 0,790 pada tahun 2011. Ini artinya perusahaan mampu menghasilkan laba sebesar $79 \%$ dari total modal yang digunakan. Di saat ROE mencapai tingkat maksimum, ini menunjukkan bahwa kinerja perusahaan semakin baik karena tingkat pengembalian investasi semakin besar.

\section{d. Pengaruh Likuiditas dan Leverage Terhadap} Profitabilitas Pada PT Hanjaya Mandala Sampoerna, Tbk yang terdaftar di Bursa Efek Indonesia

Berdasarkan hasil pengujian regresi linier berganda yang telah dilakukan, diketahui bahwa likuiditas dan leverage memiliki pengaruh positif terhadap profitabilitas perusahaan. Hal ini dapat dilihat dari persamaan regresi, yaitu $\hat{Y}=$ $0,116+0,018 X_{1}+0,546 X_{2}$. Koefisien variabel likuiditas $\left(\mathrm{X}_{1}\right)$ sebesar 0,018 , artinya jika variabel likuiditas mengalami kenaikan sebesar Rp. 1, maka profitabilitas (Y), akan mengalami peningkatan sebesar Rp. 0,018. Koefisien bernilai positif artinya terjadi hubungan positif antara likuiditas dengan profitabilitas, semakin naik likuiditas maka semakin naik profitabilitas.

Berdasarkan hasil regresi di atas, diketahui bahwa leverage memiliki pengaruh positif terhadap profitabilitas perusahaan. Besar pengaruh yang dimaksud adalah koefisien variabel likuiditas $\left(\mathrm{X}_{2}\right)$ sebesar 0,546, artinya jika variabel leverage mengalami kenaikan sebesar Rp. 1, maka profitabilitas (Y), akan mengalami peningkatan sebesar Rp. 0,546. Koefisien bernilai positif artinya terjadi hubungan positif antara leverage dengan profitabilitas, semakin naik leverage maka semakin naik profitabilitas.

Hasil analisis regresi linier berganda tersebut sesuai dengan pendapat ahli yang menyatakan ketika penggunaan utang mampu memberikan penggembalian yang tinggi maka akan dipandang baik, sebaliknya jika penggunaan utang tidak mampu memberikan pengembalian yang tinggi maka akan dipandang tidak baik.

\section{KESIMPULAN DAN SARAN \\ 1. Kesimpulan}

a. Nilai rata-rata Likuiditas yang dihitung dengan menggunakan Current Ratio (CR) adalah sebesar 2,289. Rata-rata Leverage yang dihitung dengan menggunakan debt to equity ratio (DER) adalah sebesar 0,851. Rata-rata Profitabilitas yang dihitung dengan menggunakan return on equity (ROE) perusahaan tahun 2008-2015 adalah sebesar 0,622.

b. Dari hasil analisis regresi linier berganda diperoleh $\hat{\mathrm{Y}}=0,116+0,018 \mathrm{X}_{1}+0,546 \mathrm{X}_{2}$, artinya likuiditas dan leverage berpengaruh positif terhadap profitabilitas pada PT Hanjaya Mandala Sampoerna, Tbk tahun 2008-2015.

c. Berdasarkan pengujian koefisien korelasi dan determinasi diketahui bahwa nilai $\mathrm{r}$ adalah 0,760 yang berarti bahwa terdapat korelasi yang kuat antara CR dan DER dengan ROE. Sementara untuk uji koefisien determinasi diperoleh hasil bahwa profitabilitas dapat dijelaskan oleh likuiditas dan leverage yaitu sebesar 57,8\%, sedangkan sisanya $42,2 \%$ dipengaruhi atau di 
jelaskan variabel lain yang tidak dimasukkan dalam model penelitian ini.

d. Dari hasil uji statistik $\mathrm{F}$ diperoleh hasil $\mathrm{F}_{\text {hitung }}<$ $\mathrm{F}_{\text {tabel }}$ atau dikatakan $3,420<5,79$ dan tingkat signifikansi adalah $0,116>0,05$ maka $\mathrm{H}_{0}$ diterima. Hal ini berarti secara simultan likuiditas dan leverage berpengaruh tidak signifikan terhadap profitabilitas pada PT Hanjaya Mandala Sampoerna, Tbk yang terdaftar di Bursa Efek Indonesia.

e. Dari hasil uji statistik t diperoleh hasil bahwa secara parsial untuk variabel likuiditasyang diukur dengan Current ratio (CR) mempunyai nilai $t_{\text {hitung }}$ sebesar 0,220 lebih kecil dari $t_{\text {tabel }}$ 2,571 atau $0,220<2,571$ dan tingkat signifikan $0,835>0,05$, maka $\mathrm{H}_{0}$ diterima atau dapat dikatakan CR berpengaruh tidak signifikan terhadap ROE Sementara untuk variabel leverage yang diukur dengan Debt to Equity Ratio (DER) mempunyai nilai $t_{\text {hitung }}$ sebesar 1,113 lebih kecil dari $\mathrm{t}_{\text {tabel }} 2,571$ atau $1,113<2,571$ dan tingkat signifikan $0,316>0,05$, maka $\mathrm{H}_{0}$ diterima atau dapat dikatakan DER berpengaruh tidak signifikan terhadap ROE.

\section{Saran}

a. Sebaiknya perusahaan lebih memperhatikan faktor-faktor untuk menjaga tingkat kestabilan CR. Untuk itu sebaiknya perusahaan tetap menjaga $\mathrm{CR}$ yang tinggi, dengan $\mathrm{CR}$ tinggi maka perusahaan dapat membayar hutang jangka pendek perusahaan sehingga investor beminat menanamkan modalnya di perusahaan.

b. Sebaiknya perusahaan memperhatikan faktorfaktor untuk tetap mempertahankan DER minimum. Perusahaan sebaiknya memperhatikan faktor-faktor seperti menjaga stabilitas penjualan, ukuran perusahaan, struktur aset, operating leverage, tingkat pertumbuhan perusahaan, profitabilitas, pajak, pengendalian, sikap manajemen, kondisi internal perusahaan, fleksibilitas keuangan.

c. Sebaiknya perusahaan lebih memperhatikan faktor-faktor yang mempengaruhi rendahnya
ROE seperti penjualan yang dapat meningkatkan pendapatan perusahaan. Selain itu perusahaan sebaiknya melakukan pengecekan terhadap efisiensi modal kerja semakin cepat perputaran modal kerja maka profitabilitas juga ikat meningkat.

d. Sehubungan dengan keterbatasan yang ada pada penulis, penelitian ini masih terdapat kelemahankelemahan dan belum dapat mengungkapkan seluruh variabel yang dapat mempengaruhi profitabilitas pada PT Hanjaya Mandala Sampoerna, Tbk yang terdaftar di Bursa Efek Indonesia. Sebagai bahan masukan bagi peneliti selanjutnya, perlu dilakukan penelitian analisis teknikal dan yang berhubungan dengan kondisi sosial, ekonomi dan politik untuk mengetahui pengaruhnya terhadap profitabilitas.

\section{E. DAFTAR PUSTAKA}

Atmaja, Lukas Setia. 2008. Manajemen Keuangan. $\begin{array}{lll}\text { Edisi } & 2 . & \text { Yogyakarta: }\end{array}$ Andi.

Brigham, Eugene F. Dan Joel F. Houston. 2010. Dasar-dasar Manajemen Keuangan. Buku Satu, Edisi Kesebelas. Jakarta: Salemba empat.

Horne, James C. Van dan John M. Wachowicz. 2012. Prinsip-prinsip Manajemen Keuangan. Jakarta: Salemba Empat.

Ikatan Akuntan Indonesia. 2004. Standar Akuntansi keuangan. Cetakan pertama. Jakarta: Salemba Empat.

Kasmir. 2010. Pengantar Manajemen keuangan. Edisi Pertama, Cetakan Kesatu. Jakarta: Kencana

Martani, Dwi, dkk. 2012. Akuntansi Keuangan Menengah Berbasis PSAK. Jakarta: Salemba Empat.

Mardiyanto, Handoko. 2008. Intisari Manajemen Keuangan. Jakarta: Grasindo.

Sudana, I Made. 2011. Manajemen Keuangan Perusahaan Teori dan Praktek. Jakarta: Erlangga. 